\title{
PENERAPAN MANAJEMEN KURIKULUM DALAM MENINGKATKAN KETERAMPILAN SOSIAL (Social Skill) DI MAN DARUSSALAM CIAMIS
}

\author{
Tatang Ibrahim \\ UIN Sunan Gunung Djati Bandung \\ Email: ta2ngibra@yahoo.co.id
}

\begin{abstract}
This study aims to determine the curriculum planner in improving social skills (social skills), the implementation of curriculum in improving social skills (social skill), the form of curriculum evaluation so far in improving social skills (especially skill) in the skills lessons held in MAN Darussalam Ciamis.

This study is a qualitative descriptive analytic study of data collection is done by data collection techniques documentation, observation, and in-depth interviews (In depth interview). To analyze the data, this study uses inductive data analysis with an inductive approach opening the possibility to perform discovery or discovery.

The results of this study show that: (1) Planning of curriculum in improving social skill (social skill) in MAN Darussalam Ciamis implemented by way of compilation of vision, mission, and purpose of education, education calendar, curriculum structure. (2) The implementation of curriculum in improving social skills in MAN Darussalam Ciamis covers the implementation of programmed activities consisting of: religious, social, bilingual program. (3) The form of evaluation of curriculum in improving social skill (social skill) in MAN Darussalam Ciamis, is carried out with two stages: writing test and individual practice test. With held the examinations were able to improve the social skills of learners because in addition to getting the material also directly practice with the tools of existing skills.
\end{abstract}

\begin{abstract}
Abstrak
Penelitian ini bertujuan untuk mengetahui perencanaa kurikulum dalam meningkatkan keterampilan social (social skill), pelaksanaan kurikulum dalam meningkatkan keterampilan sosial (social skill), bentuk evaluasi kurikulum selama ini dalam meningkatkan keterampilan sosial (social skill) khususnya dalam pelajaran keterampilan yang di selenggarakan di MAN Darussalam Ciamis.

Penelitian ini merupakan penelitian kualitatif deskriptif analitik pengumpulan data dilakukan dengan teknik pengumpulan data dokumentasi, observasi, dan wawancara mendalam (In depth interview). Untuk menganalisis data, penelitian ini menggunakan analisis data induktif dengan pendekatan induktif membuka kemungkinan untuk melakukan penemuan atau discovery.

Hasil penelitian ini menunjukan bahwa: (1) Perencanaan kurikulum dalam meningkatkan keterampilan sosial (social skill) di MAN Darussalam Ciamis dilaksanakan dengan cara penyusunan visi, misi, dan tujuan pendidikan, kalender pendidikan, struktur kurikulum. (2) Pelaksanaan kurikulum dalam meningkatkan keterampilan sosial (social skill) di MAN Darussalam Ciamis meliputi pelaksanaan kegiatan terprogram yang terdiri dari: program keagamaan, social, bilingual. (3) Bentuk evaluasi kurikulum dalam meningkatkan keterampilan sosial (social skill) di MAN Darussalam Ciamis ini, di laksanakan dengan dua tahap yaitu: ujian tulis dan ujian praktik secara individu. Dengan diadakan ujianujian tersebut ternyata mampu meningkatkan keterampilan sosial peserta didik kerena selain mendapatkan materi juga langsung mempraktikan dengan alat-alat keterampilan yang ada.
\end{abstract}

Kata Kunci: Manajemen Kurikulum, Keterampilan Sosial (social skill) 


\section{A. PEndahuluan}

Pendidikan dinilai sangat penting karena mengingat dapat mengembangkan peserta didik potensi dirinya untuk memiliki kekuatan spiritual keagamaan, pengendalian diri kepribadian, kecerdasan, akhlak mulia, serta keterampilan yang diperlukan dirinya, masyarakat, bangsa dan negara.

Pendidikan merupakan wahana bagi generasi muda untuk mendapatkan kecakapan hidup (life Skill) dengan harapan peserta didik dapat memasuki kehidupan masyarakat. Pendidikan mempunyai peran yang sangat menentukan tidak hanya bagi perkembangan dan pertumbuhan individu, tetapi juga bagi pembangunan suatu bangsa. Pendidikan yang mampu mendukung pembangunan adalah pendidikan yang bermutu yaitu pendidikan yang mampu menghadapi dan memecahkan problem kehidupan yang dihadapi. Pemikiran itu semakin terasa ketika seseorang akan memasuki dunia kerja dan kehidupan di masyarakat sebab peserta didik dituntut untuk mampu menerapkan apa yang dipelajari di sekolah serta mampu menghadapi problem kehidupan sehari-hari. Akan tetapi hasil pendidikan itu dikatakan baik atau buruknya pendidikan ditentukan oleh kurikulum, apakah mampu membangun kesadaran kritis terhadap peserta didik ataukah tidak.

Pendidikan seharusnya dibekali dengan beberapa keterampilan kerja, yang diharapkan peserta didik mampu mentransformasikan yang dipelajari di sekolah sehingga dapat bermanfaat di lingkungan masyarakat, apa lagi pada arus globalisasi ini, persaingan dalam dunia kerja sangat ketat, karena setiap perusahaan selain bersaing dengan perusahaan-perusahaan yang ada di dalam negeri juga bersaing dengan perusahaan-perusahaan luar negeri, oleh karena itu dalam dunia kerja hanya dapat dimasuki oleh seseorang yang memiliki pendidikan dan keterampilan. Dalam hal ini tidak terlepas dari kurikulum yang ada dalam undang - undang No 20 tahun 2003 pasal 36 ayat 3 yang berbunyi sebagai berikut:

Kurikulum disusun sesuai dengan jenjang pendidikan dalam kerangka Negara Kesatuan Republik Indonesia dengan memperhatikan:

Peningkatkan iman dan takwa, Peningkatkan akhlak mulia, Peningkatan potensi, kecerdasan, dan minat peserta didik, Keragaman potensi daerah dan nasional, Tuntutan pembangunan daerah dan nasional, Tuntutan dunia kerja, Perkembangan ilmu pengetahuan, teknologi dan seni, Agama, Dinamika perkembangan global, Persatuan nasional dan nilai -nilai kebangsaan.

Kebijakan tersebut menunjukan agar lembaga pendidikan tidak hanya menyelenggarakan kurikulum produk Kementerian Pendidikan dan Kebudayaan maupun Kementrian Agama saja, tetapi juga menyelenggarakan kurikulum muatan lokal yang berorientasi pada dunia kerja. Sehingga peserta didik memiliki kemandirian ekonomi sejak dini, seperti halnya di MAN Darussalam ciamis. Lembaga ini mengembangkan kurikulum dengan menambah berbagai keterampilan sosial antara lain : untuk para siswa dan siswi dapat memiliki wawasan wirausaha dan berjiwa mandiri yang didukung dengan kegiatan koperasi siswa, bazaar, pelatihan komputer akuntansi dan ekonomi syari'ah.

Keterampilan sosial memiliki suatu tujuan atau harapan seperti pada artikel jurnal Purwanti keterampilan sosial yang diharapkan dari siswa itu tidak hanya itu melainkan keterampilan sosial tersebut meliputi kemampuan memecahkan masalah, kemampuan berkomunikasi, menjalin hubungan dengan orang lain, menghargai diri sendiri dan orang lain, mendengarkan pendapat atau keluhan dari orang lain, memberi atau menerima feedback, memberi atau menerima kritik, bertindak sesuai norma dan aturan yang berlaku.

Berdasarkan pendeskripsian diatas bahwa ada kaitanya atau pengaruhnya antara manajemen kurikulum dengan keterampilan sosial.

Manajemen kurikulum pendidikan sangat penting,karena tanpa adanya manajemen maka pendidikan tidak akan dapat berjalan dengan baik Kurikulum merupakan program pendidikan yang disediakan oleh lembaga pendidikan (sekolah) bagi peserta didik. Berdasarkan program pendidikan tersebut siswa melakukan berbagai kegiatan belajar, sehinga mendorong perkembangan dan pertembuhannya sesuai dengan tujuan pendidikan yang telah ditetapkan. Dengan kata lain, dengan program kurikuler tersebut, sekolah menyediakan lingkungan pendidikan bagi peserta didik untuk berkembang. Itu sebabnya, kurikulum disusun sedemikian rupa yang memungkinkan peserta didik melakukan beraneka ragam kegiatan belajar, kurikulum tidak terbatas pada sejumlah mata pelajaran, namun meliputi segala sesuatu yang dapat mempengaruhi perkembangan peserta didik, seperti : bangunan sekolah, alat pelajaran, perlengkapan sekolah, perpustakaan, karyawan tata usaha, gambar-gambar, halaman sekolah, dan lain lain. Kurikulum sebagai satu komponen yang menentukan dalam suatu sistem pendidikan.

Menurut (Gunawan 2012: 3) kurikulum mer upakan alat untuk mencapai tujuan pendidikan dan sekaligus sebagai pedoman dalam pelaksanaan pembelajaran pada semua jenis dan jenjang pendidikan. Sementara Daradjat (Gunawan 2012 :4) mengatakan bahwa kurikulum sebagai suatu program yang 
direncanakan dalam pendidikan dan dilaksanakan untuk mencapai sejumlah tujuan tujuan pendidikan tertentu. Pengertian tersebut lebih luas tidak hanya mencakup materi pelajaran saja tetapi sejumlah mata pelajaran atau kegiatan yang mencakup program pendidikan agar mencapai tujuan pendidikan yang diharapkan.

Kurikulum merupakan alat kunci dalam proses pendidikan formal, tidak mengherankan jika kurikulum itu selalu diperbaiki dan ditinjau kembali untuk mengikuti perkembangan ilmu pengetahuan. Oleh karena itu kurikulum diharapkan selalu berkembang, tetapi kurikulum juga perlu dibina penerapan dan prospeknya.

Tidak hanya dalam ilmu pengetahuan, kurikulum juga harus dikembangkan dalam bidang keterampilan sosial guna mempersiapkan peserta didik yang mempunyai pengetahuan dan keterampilan untuk mengimbangi tuntutan dunia kerja pada saat ini, Oleh karena itu peserta didik sebagai calon tenaga kerja perlu diberikan kesempatan dan dikondisikan dalam suatu pendidikan yang dapat memberikan kompetensi dalam pribadi peserta didik tersebut, sehingga disamping mempunyai pengetahuan luas yang dilihat sebagai kualitas diri, peserta didik juga mempunyai kompetensi yang berintikan keterampilan dasar yang dapat dikembangkan guna menjadi masyarakat yang produktif.

Kurikulum adalah landasan yang digunakan pendidik untuk membimbing peserta didiknya ke arah tujuan pendidikan yang diinginkan melalui akumulasi sejumlah pengetahuan, keterampilan, dan sikap mental. Oleh karena itu penerapan manajemen kurikulum perlu dilaksanakan sesuai dengan tujuan pendidikan suatu madrasah/sekolah yang mengacu pada konseptualisasi manusia paripurna melalui transformasi sejumlah pengetahuan, keterampilan, dan sikap mental yang harus tersusun dalam kurikulum Pendidikan Islam.

Seperti halnya penerapan manajemen kurikulum di MAN Darussalam Ciamis yang penerapan kurikulumnya tidak hanya terpacu pada kurikulum Kementerian Agama dan Kementerian Pendidikan dan kebudayaan saja, akan tetapi MAN Darussalam Ciamis ini mempunyai terobosan baru dengan menambah materi pembelajaran dengan materi-materi keterampilan seperti: keterampilan sosial antara lain : untuk para siswa dan siswi dapat memiliki wawasan wirausaha dan berjiwa mandiri yang didukung dengan kegiatan koperasi siswa, bazaar, pelatihan komputer akuntansi dan ekonomi syari'ah. Selain itu program - program unggulan keagamaan seperti menguasai ilmuilmu keislaman yang bersumber langsung pada kitab-kitab Turats dan Modern, dan berkomunikasi Arab/Inggris secara aktif. Program ini didukung dengan tutorial dan
Tahfidz al-Qur'an, serta pembelajaran berbasis ICT. Program unggulan lainya yaitu program ilmu pengetahuan program ini mengembangkan lifeskill peserta didik dengan berbagai kegiatan diantaranya : budidaya tanaman hias, praktek biologi dan kesehatan serta apotik hidup, kimia, fisika dan matematika.

Kebutuhan akan tenaga kerja yang handal menuntut sistem pendidikan untuk mempersiapkan Sumber Daya Manusia (SDM) yang unggul dan mampu mengisi berbagai lapangan kerja yang tercipta dalam proses pembangunan. Dalam konteks ini di lembaga pendidikan islam, khususnya di Madrasah Aliyah yang tidak memadai lagi sekedar pengawetan transfer dan transmisi ilmu-ilmu saja, tetapi sekaligus juga harus dapat memberikan keterampilan (Skill) dan kemampuan (abilities) kepada seluruh peserta didik. Madrasah Aliyah dalam kaitannya ini perlu adanya terobosan, misalnya dengan memasukan dan mengembangkan sekolah sekolah keterampilan (vocations schools).

Dengan ini Madrasah Aliyah dapat memasukan kurikulum muatan lokal yang mengisi tentang keterampilan kepribadian yang berguna untuk masa depan nanti. Kurikulum dapat dipandang sebagai suatu rancangan pendidikan, sebagai suatu rancangan, kurikulum menentukan pelaksanaan dan hasil pendidikan. kita ketahui bahwa mempersiapkan generasi muda untuk terjun di lingkungan masyarakat tidaklah semudah kita membalikan telapak tangan, namun dengan memberikan pendidikan keterampilan dapat membantu peserta didik untuk terjun di lingkungan masyarakat. Pendidikan bukan hanya sebagai kegiatan transfer ilmu saja, akan tetapi pendidikan juga harus memberikan bekal pengetahuan, keterampilan, serta nilai - nilai untuk hidup, bekerja, dan mencapai perkembangan lebih lanjut di masyarakat. Peserta didik berasal dari masyarakat mendapatkan pendidikan baik formal maupun informal dalam lingkungan masyarakat, dan diarahkan bagi kehidupan dalam masyarakat pula. kehidupan masyarakat dengan segala karakteristik dan kekayaan budayanya, menjadi landasan dan acuan bagi pendidikan.

Kurikulum juga mengalami perkembangan sesuai dengan perkembangan ilmu pengetahuan dan teknologi. perkembangan kurikulum ialah proses perencanaan kurikulum agar menghasilkan rencana kurikulum yang luas dan spesifik.

Dalam proses ini kurikulum tak hanya terpacu kepada Standar Nasional Pendidikan, namun kurikulum dikembangkan sesuai dengan kondisi dan potensi daerah masing - masing, sehingga peserta didik tidak hanya dituntut untuk melanjutkan ke jenjang perguruan tinggi, akan tetapi peserta didik juga dapat 
menjalankan atau mengembangkan keterampilan yang sudah diberikan di sekolah untuk hidup di lingkungan masyarakat.

Potret yang ada di lembaga pendidikan sekarang ini sedikit sekali lembaga pendidikan yang mengembangkan kurikulum dalam tuntutan dunia kerja, khususnya Sekolah Menengah Atas (SMA)/Madrasah Aliyah (MA) yang prospeknya dituntut untuk melanjutkan ke jenjang pendidikan yang lebih tinggi, akan tetapi apa dayanya masyarakat menengah ke bawah yang tidak mempunyai kemampuan dalam bentuk material, sehingga banyak yang tidak bias melanjutkan.

Perlunya bakat dan keterampilan ditingkatkan pada peserta didik pada era globalisasi ini. Di sekolah/madrasah menjadi penting sebagaimana realitas yang terjadi, sehingga pendidikan di sekolah/madrasah tidak hanya terfokuskan pada aspek kognitif yang cenderung teoritik, tekstual dan bukan pada pendidikan kontekstual. seperti halnya tanpa mempertimbangkan bakat dan keterampilan peserta didik, sehingga banyak dijumpai pada peserta didik lulus sekolah banyak yang pengangguran tanpa memperoleh keterampilan dan kecakapan tertentu sebagai bekal masa depannya.

Berangkat dari permasalahan di atas kiranya sudah memberikan gambaran dimana letak signifikansi permasalahan dari topik yang menjadi penelitian ini. Penelitian ini lebih menekankan pada penerapan manajemen kurikulum dalam meningkatkan keterampilan sosial (social skill).

\section{B. TUJUAN PENELITIAN}

Tujuan yang diharapkan pada penelitian ini adalah: untuk mengetahui perencanaa kurikulum dalam meningkatkan keterampilan social (social skill), pelaksanaan kurikulum dalam meningkatkan keterampilan sosial (social skill), bentuk evaluasi kurikulum selama ini dalam meningkatkan keterampilan sosial (social skill) khususnya dalam pelajaran keterampilan yang di selenggarakan di MAN Darussalam Ciamis.

\section{METODE PENELITIAN}

Penelitian ini menggunakan metode kualitatif maka rancangan penelitian ini sewaktu -waktu masih bias mengalami perbaikan tergantung situasi dan kondisi dilapangan. Selain itu, jenis penelitian kualitatif ini juga belum memiliki teori yang baku menjadi landasan penelitian. Akan tetapi, penelitian ini dilakukan dengan mengacu pada kerangka teori yang sudah disusun dari beberapa referensi sehingga bias dijadikan panduan dalam penelitian penerapan manajemen kurikulum dalam meningkatkan keterampilan sosial (Social Skill) di MAN Darussalam Ciamis.

\section{HASIL DAN PEMBAHASAN}

Sebelum membahas hasil dan pembahasan. Penelitian ini sependapat dengan pendapat dahlan bahwa kurikulum terdiri 4 aspek penting yakni : Kompetensi : Beban yang harus dikuasai oleh peserta didik selama mengikuti program pembelajaran. Komptensi tersebut tertuang dalam mata pelajaran atau mata kuliah yang diberikan dengan kriteria tertentu. Peserta Didik : Subjek yang melakukan belajara (pebelajara). Peserta didik dituntut untuk menguasai beberapa kompetensi minimal agar dapat dikatakan melewati suatu jenjang tertentu. Pelaksana : Suatu lembaga yang bertanggung jawab dalam meingimplemtasikan kurikulum. Pelaksana pada awalnya hanya terdiri dari satu lembaga yakni sekolah yang menanungi peserta didik, namun dalam skala nasional tentu saja dibutuhkan banyak lembaga yang berperan untuk mengarahkan peserat didik tetap berada pada jalur yang sesuai. Evaluasi : Sistem evaluasi adalah proses penilaian proses implemntasi kurikulum secara keseluruhan. Evaluasi akan menilai seluruh proses baik secara partial maupun terintegrasi dengan tujuan melakukan perbaikan terhadap aspek-aspek yang ada dalam program atau bahkan program secara keseluruhan jika dianggap gagal dalam melaksanakan tujuan kurikulum.

Perencanaan kurikulum

dalam meningkatkan keterampilan sosial (social skill) di MAN Darussalam Ciamis dilaksanakan dengan cara penyusunan visi, misi, dan tujuan pendidikan, kalender pendidikan, struktur kurikulum.

Perencanaan kurikulum sebagai pedoman atau alat manajemen yang berisi petunjuk tentang jenis dan sumber peserta yang diperlukan, media penyampaian, tindakan yang perlu dilakukan, sumber biaya, sarana yang diperlukan, tenaga, system kontrol, evaluasi, dan peranan unsure - unsure ketenagaan untuk mencapai tujuan manajemen organisasi.

Selain itu perencanaan kurikulum sebagai penggerak roda organisasi dan tata laksana untuk menciptakan perubahan terhadap peserta didik sesuai dengan tujuan lembaga pendidikan.

Perencanaan kurikulum juga memiliki fungsi sebagai motivasi untuk melaksanakan system pendidikan untuk mencapai hasil yang optimal.

Pelaksanaan kurikulum dalam meningkatkan keterampilan sosial (social skill) di MAN Darussalam Ciamis meliputi pelaksanaan kegiatan terprogram yang terdiri dari: program keagamaan, social, bilingual.

Pelaksanaan kurikulum dibagi menjadi dua tingkatan, yaitu pelaksanaan kurikulum tingkat sekolah bahwa kepala sekolah yang bertanggungjawab untuk melaksanakan kurikulum di lingkungan sekolah yang dipimpin, sedangkan pada pelaksanaan 
kurikulum kelas, maka yang bertanggung jawab adalah guru.

Evaluasi krikulum adalah suatu kegiatan untuk memperbaiki substansi kurikulum, metode instruksional, prosedur implemntasi, serta pengaruhnya pada belajar dan perilaku siswa. Sedangkan untuk sistem penilaian kurikulum berdasarkan pada seperangkat criteria yang disepakati dan dapat dipertanggungjawabkan untuk membuat keputusan untuk membuat kurikulum.

Bentuk evaluasi kurikulum dalam meningkatkan keterampilan sosial (social skill) di MAN Darussalam Ciamis ini, di laksanakan dengan dua tahap yaitu: ujian tulis dan ujian praktik secara individu. Dengan diadakan ujianujian tersebut ternyata mampu meningkatkan keterampilan sosial peserta didik kerena selain mendapatkan materi juga langsung mempraktikan dengan alat-alat keterampilan yang ada.

\section{E. PENUTUP}

1) Kesimpulan

Setelah mengadakan penelitian tentang penerapan manajemen kurikulum dalam meningkatkan keterampilan sosial (Social Skill) di MAN Darussalam Ciamis dapat menarik kesimpulan bahwa:

1. Perencanaan kurikulum dalam meningkatkan keterampilan sosial (Social Skill) di MAN Darussalam Ciamis yang mencangkup pada visi, misi, dan tujuan pendidikan, kalender pendidikan, struktur kurikulum beserta data rancangan pendidikan yang memasukan mata pelajaran keterampilan ke dalam kurikulum tingkat satuan pendidikan (KTSP).

2. Pelaksanaan kurikulum dalam meningkatkan keterampilan sosial (social skill) di MAN Darussalam Ciamis meliputi pelaksanaan kegiatan terprogram yang terdiri dari: keterampilan sosial antara lain : untuk para siswa dan siswi dapat memiliki wawasan wirausaha dan berjiwa mandiri yang didukung dengan kegiatan koperasi siswa, bazaar, pelatihan komputer akuntansi dan ekonomi syari'ah. Selain itu program - program unggulan keagamaan seperti menguasai ilmu-ilmu keislaman yang bersumber langsung pada kitab-kitab Turats dan Modern, dan berkomunikasi Arab/Inggris secara aktif. Program ini didukung dengan tutorial dan Tahfidz al-Qur'an, serta pembelajaran berbasis ICT. Program unggulan lainya yaitu program ilmu pengetahuan program ini mengembangkan lifeskill peserta didik dengan berbagai kegiatan diantaranya : budidaya tanaman hias, praktek biologi dan kesehatan serta apotik hidup, kimia, fisika dan matematika.

3. Hasil pelaksanaan perencanaan manajemen kurikulum dalam meningkatkan keterampilan sosial (social skill) di MAN Darussalam Ciamis untuk para siswa dan siswi dapat memiliki wawasan wirausaha dan berjiwa mandiri yang didukung dengan kegiatan koperasi siswa, bazaar, pelatihan komputer akuntansi dan ekonomi syari'ah. Selain itu program - program unggulan keagamaan seperti menguasai ilmu-ilmu keislaman yang bersumber langsung pada kitab-kitab Turats dan Modern, dan berkomunikasi Arab/Inggris secara aktif. Program ini didukung dengan tutorial dan Tahfidz al-Qur'an, serta pembelajaran berbasis ICT. Program unggulan lainya yaitu program ilmu pengetahuan program ini mengembangkan lifeskill peserta didik dengan berbagai kegiatan diantaranya : budidaya tanaman hias, praktek biologi dan kesehatan serta apotik hidup, kimia, fisika dan matematika. Semua keterampilan tersebut dapat ditinjau dari hasil ujian, baik ujian tulis maupun ujian praktik secara individu, dan juga ditinjau dari alumni yang sudah memiliki usaha sendiri - sendiri.

\section{2) Saran}

1. Mempertahankan dan meningkatkan kembali perencanaan, pelaksanaan mata pelajaran keterampilan agar manajemen kurikulum khususnya dalam memasukan mata pelajaran keterampilan sosial dapat berjalan sesuai tujuan yang diharapkan.

2. Mata pelajaran keterampilan sebagai program unggulan di MAN Darussalam Ciamis, seharusnya ada penambahan waktu pembelajaran sehingga peserta didik bias lebih meningkatkan keterampilan yang dimiliki.

3. Sebagai penunjang kegiatan keterampilan yang dimiliki peserta didik, khususnya sarana prasarana keterampilan sosial yang ada di sekolah. 
4. Guru keterampilan hendaknya mempertahankan dan meningnkatkan kembali kualitas pembelajaran yang disajikan dan meningkatkan kreatifitas dalam penyajian materi sesuai rencana pembelajaran yang dibuat.

\section{DAFTAR PUSTAKA}

Dahlan Ahmad. Pengertian Kurikulum Dalam Dunia Pendidikan. 2017

http://www.ahmaddahlan.net/2017/01/pe ngertian-kurikulum-pendidikan-dan4.html. diunduh Agustus.2017

Dokumen Kurikulum MAN Darussalam Ciamis. 2017

Eko Sony. Penerapan Manajemen Kurikulum Dalam Meningkatkan Keterampilan Kerja (Work Skill) Di Madrasah Aliyah Sunan Kalijaga Patianrowo Nganjuk Jawa Timur. 2013.

Muhammad Ali. Pengembangan Kurikulum Di Sekolah. Bandung: Sinar Baru Offset. 2005.

Moh Yamin. Manajemen Mutu Kurikulum Pendidikan (Panduan Menciptakan Mutu Kurikulum yang Progresif dan Inspiratif). Yogyakarta: Diva Press. 2009.

Oemar Hamalik. Manajemen Pengembangan Kurikulum. Bandung: PT Remaja Rosdakarya. 2008

Peraturan Pemerintah No 19 Tahun 2005 tentang Standar Nasional Pendidikan.

Peraturan Menteri Pendidikan Nasional No 24 tahun 2007 tentang Standar Sarana dan Prasarana

Purwanti, E., Purnomo, E., \& Pujiati, P. (2015). Pengembangan Instrumen Keterampilan Sosial Berbasis Observasi Dan Sosiometri Dalam Pembelajaran Ips. Jurnal Studi Sosial, 3(1).

http://eprints.ums.ac.id/27377/4/02_BAB_I.pdf 